\title{
Lymphoblasts with Surface Immunoglobulin Present
}

National Cancer Institute

\section{Source}

National Cancer Institute. Lymphoblasts with Surface Immunoglobulin Present. NCI

Thesaurus. Code C150656.

A microscopic finding indicating that immunoglobulins are bound to or expressed on the surface of the immature lymphoid cells in a sample. 